\title{
Investigation of Antioxidant Activity and Physicochemical Properties of Local and Branded Honeys in Sindh, Pakistan
}

\author{
Muhammad Farooque Lanjwani ${ }^{*}$, Fayaz Ahmed channa ${ }^{2}$ \\ ${ }^{1}$ Dr. M. A. Kazi Institute of Chemistry, University of Sindh, Jamshoro, Pakistan \\ ${ }^{2}$ Department of Islamiyat, University of Sindh, Jamshoro, Pakistan \\ E-mail: mfarooquechemist@yahoo.com
}

\begin{abstract}
The honey is a sweetest natural products because it have unique properties, which honey bees are collect from dissimilar plants materials. The honey is used as a nutritional purposes for human consumption and also use for medicinal and industrial purposes. The honey also an important product in the international markets. The present study was conducted to analyzed the physicochemical and antioxidant activities of different honey samples in Sindh Pakistan. The 15 honey samples were analyzed for parameters including $\mathrm{pH}$, electrical conductivity, moisture, viscosity, ash\%, density and antioxidant activity. The average value of $\mathrm{pH}$ was founded 3.78 electrical conductivity $2492 \mu \mathrm{S} / \mathrm{cm}$, viscosity $12.34 \mathrm{mpa}$, moisture $15.99 \%$, density 0.78 and average value of antioxidant activity was founded $19.12 \mathrm{mg} / 100 \mathrm{~g}$.
\end{abstract}

Keywords: antioxidant activity, local and branded honey, phyicochemical analysis, Sindh

\section{Introduction}

Honey is one of the natural sweetest substance produced by honey bees, from nectar of different plants (blossoms) and from the excretions of living parts of the plants ${ }^{[1]}$. The chemical composition of honey depends single or multi floral types, geographical, botanical origin of the nectars and different environmental conditions. Numerous natural components of honey used as an indicator to determine the floral, botanical and geographical origin of the product. Basically, natural honey is viscous and sticky liquid which content of $80-85 \%$ carbohydrate (fructose and glucose), $15-17 \%$ water, $0.1-0.5 \%$ protein, $0.2 \%$ ash and also trace level of minerals, amino acids, vitamins and enzymes as well as some other constituents like phenolic compound and antioxidants also present ${ }^{[2,3]}$. The honey is used as a different medicinal purposes in the world ${ }^{[1]}$. The major components of honey are approximately equal in all honey samples, the chemical and physical properties of natural honeys change according to the types of plants and different factors that may affect the properties of the honey ${ }^{[4,5]}$.

Honey is an oldest well-known as medicines and it was appreciated extremely in the world. Honeybees are possessed enzymes that catalyzed the sucrose into fructose and glucose. Honey in fact, is mainly a combination of these three sugars. The honey is used for several diseases like urinary, respiratory, gastrointestinal, ulcers, skin, wounds, dandruff, eczema, psoriasis diseases ${ }^{[6,7]}$.

The main objective of the present study to examine the quality of local and branded honey in the study area because no any previous work were reported on the physico-chemical and antioxidant activity of the honey in the Sindh, Pakistan.

\subsection{Review of literature}

There is no work reported on the antioxidant activity and physicochemical on the honey in Sindh but less work was reported in the Pakistan.

Zahoor et al. ${ }^{[8]}$ Determined the antibacterial, antifungal and antioxidant activities of honey, collected from Timergara (Dir, Pakistan).

Ahmed M et al. ${ }^{[9]}$ Analyzed the Physiochemical, biochemical, minerals content and antioxidant potential of national and international honeys in Pakistan and results were found between $\mathrm{pH} 3.38$ to 4.28, moisture 10.10 to 19.2 (\%), ash 0.04 to $0.22(\mathrm{~g} / 100 \mathrm{~g})$.

Gulfraz M et al. ${ }^{[10]}$ Quality assessment of various types of honey of Pakistan and results were found between $\mathrm{pH} 3.32$ to 6.5 , moisture 18.0 to $36.8(\%)$, ash 0.13 to $0.44(\mathrm{~g} / 100 \mathrm{~g})$.

Farooq Khan $\mathrm{Z}$ et al. ${ }^{[1]]}$ Physical and spectroscopic characterization of Pakistani honey from Pakistan and results

Copyright (C2020 Muhammad Farooque Lanjwani et al.

DOI: https://doi.org/10.37256/sce.11202079.43-50

This is an open-access article distributed under a CC BY license

(Creative Commons Attribution 4.0 International License)

https://creativecommons.org/licenses/by/4.0/ 
varied from $\mathrm{pH} 4.2$ to 4.3 , moisture 16.60 to 16.7 (\%), ash 0.30 to $0.38(\mathrm{~g} / 100 \mathrm{~g})$, density 1.50 to $155 \mathrm{~g} / \mathrm{cm}$.

Lanjwani M F, Channa F. A ${ }^{[12]}$ Minerals content in different types of local and branded honey in Sindh, Pakistan and analyzed different minerals like $\mathrm{Na}, \mathrm{Ca}, \mathrm{K}, \mathrm{Mg}, \mathrm{Fe}, \mathrm{Cu}, \mathrm{Zn}, \mathrm{Mn}, \mathrm{Ni}, \mathrm{Cr}, \mathrm{Cd}, \mathrm{Co}, \mathrm{Pb}$.

\section{Materials and methods}

\subsection{Sample collection and preparation}

The total fifteen (15) honey samples were collected from different parts of Sindh, 8 honey samples were collected from different locations of the study areas and 7 samples were purchased from local market Hyderabad Sindh (table 1) and analyzed for antioxidant activity, electrical conductivity, $\mathrm{pH}$, ash\%, moisture, specific gravity and viscosity. All honey samples were freshly collected in the clean containers and labeled numbers, date of collection and place and samples were kept at normal temperature until analyzed.

Table 1. Name of sampling stations of honey samples

\begin{tabular}{ccc}
\hline Sample stations & Sampling stations name & Name of branded company \\
\hline 1 & Local honey & Collected by local peoples \\
2 & Local honey & Collected by local peoples \\
3 & Local honey & Collected by local peoples \\
4 & Branded honey & Purchase from local market Hyderabad \\
5 & Local honey & Collected by local peoples \\
6 & Local honey & Collected by local peoples \\
7 & Local honey & Collected by local peoples \\
8 & Local honey & Collected by local peoples \\
9 & Local honey & Collected by local peoples \\
10 & Branded honey & Purchase from local market Hyderabad \\
11 & Branded honey & Purchase from local market Hyderabad \\
12 & Branded honey & Purchase from local market Hyderabad \\
13 & Branded honey & Purchase from local market Hyderabad \\
14 & Branded honey & Purchase from local market Hyderabad \\
15 & Branded honey mixed rayal jelly & Purchase from local market Hyderabad \\
\hline
\end{tabular}

\subsection{Samples analysis}

The $\mathrm{pH}$ was examined by (Orion 5 Star) pH meter, kinematic Viscosity, Specific gravity, moisture content and Ash content and antioxidant activity were analyzed using standard analytical methods. The electrical conductivity was analyzed with Orion 115 conductivity meter ${ }^{[13,14]}$. The Viscosity was analyzed by using ASTM D method ${ }^{[15]}$ the constant temperature was used to change the dilutions of honey, 5 gram honey sample was taken and diluted by Xylene with percentage $50 \%$, then honey sample was put into the viscometer which was already maintained at hot bath at $40{ }^{\circ} \mathrm{C}$ and $60{ }^{\circ} \mathrm{C}$, and then viscosity was measured. Moisture content of honey was determined by using methods Association of the Official Analytical Chemists ${ }^{[16]}$. The $2 \mathrm{~g}$ of sample was taken in the china dish, and placed in oven at $80^{\circ} \mathrm{C}$ for 2 to 3 hours until constant weight was achieved. The content of moisture was expressed as loss in weight of wet honey samples.

Moisture content was calculated as follows

$$
\% \text { Moisture }(\mathrm{w} / \mathrm{w})=\frac{\mathrm{W}_{\mathrm{t}} \text { : of wet Sample }-\mathrm{W}_{\mathrm{t}} \text { : of dry Sample }}{\mathrm{W}_{\mathrm{t}} \text { : of wet Sample }} \times 1100
$$

Ash content in different honey samples were determined by using method ${ }^{[17]}$. The $4 \mathrm{~g}$ of honey sample was taken in crucible and kept in a muffle furnace for 4 hours at $550{ }^{\circ} \mathrm{C}$. Then crucible was cooled in the desiccators and then weighed. Percentage $\%$ of ash content was determined by the resulting inorganic residue. Weight of ash obtained in percentage as follows

$$
\% \text { Ash }=\frac{\mathrm{W}_{\mathrm{t}}: \text { of Ash }}{\mathrm{W}_{\mathrm{t}}: \text { of wet Sample }} \times 100
$$

The density of honey samples were analyzed with the help of hydrometer cylinder. The honey sample was transferred to hydrometer cylinder, which was already set at same temperature. When temperature reached at equilibrium position then the hydrometer scale was observed and results were noted. The antioxidant activity was determined used method ${ }^{[18]}$. Taken $0.2 \mathrm{~mL}$ of samples in the test tubes and added $2 \mathrm{~mL}$ of $0.6 \mathrm{M} \mathrm{H}_{2} \mathrm{SO}_{4}$, and $28 \mathrm{mM}$ sodium phosphate and also $4 \mathrm{mM}$ 
ammonium molybdate was added in duplicate. After that tubes were capped using aluminum foil and kept in water bath at $96^{\circ} \mathrm{C}$ for 95 minutes than samples were cooled at room temperature. The blank was prepared by using same procedure using deionized water instead of sample and absorbance was carried at $695 \mathrm{~nm}$ with the help of UV-visible Spectrophotometer. Standard calibration curve was prepared by using different concentrations $(0.1,0.2,0.3,0.4,0.5$, and 0.6 $\mathrm{ppm}$ ) of tocopherol. The statistical analysis like correlation coefficient, principal component and cluster analysis were also determined to interpretive the data using SPSS version 22 software.

\section{Results and discussion}

The seven parameters of 15 local and branded honey samples were analyzed to check the quality of honey of study area Sindh.

\subsection{Antioxidant property, viscosity and moisture contents in honey samples}

Honey is used subsequently from long period both domestic and medical uses, recently antioxidant activity has come to attention, with increasing demand of antioxidant activity in food, honey is a famous as a source of the antioxidant activity ${ }^{[19]}$. The oxidative stress results lack of balancing chemical reaction among the production of free radicals and also natural protective effect of our body resulting disruption of genetic structure and cellular damage ${ }^{[20]}$. The antioxidant activity of the honey are phenols, chyrsin, quercetin, hesperetin and maillard products called melanoidins. The antioxidant activity of honey was found from 11.09 to $40.08 \mathrm{mg} / 100 \mathrm{~g}$. The lowest level of antioxidant activity was founded in sample $10,11.09 \mathrm{mg} / 100 \mathrm{~g}$ and highest was in sample $6,40.08 \mathrm{mg} / 100 \mathrm{~g}$ (table 2, figure 1). It is observed that antioxidant activity of local honey were higher than branded honey which were purchased from local market Hyderabad Sindh.

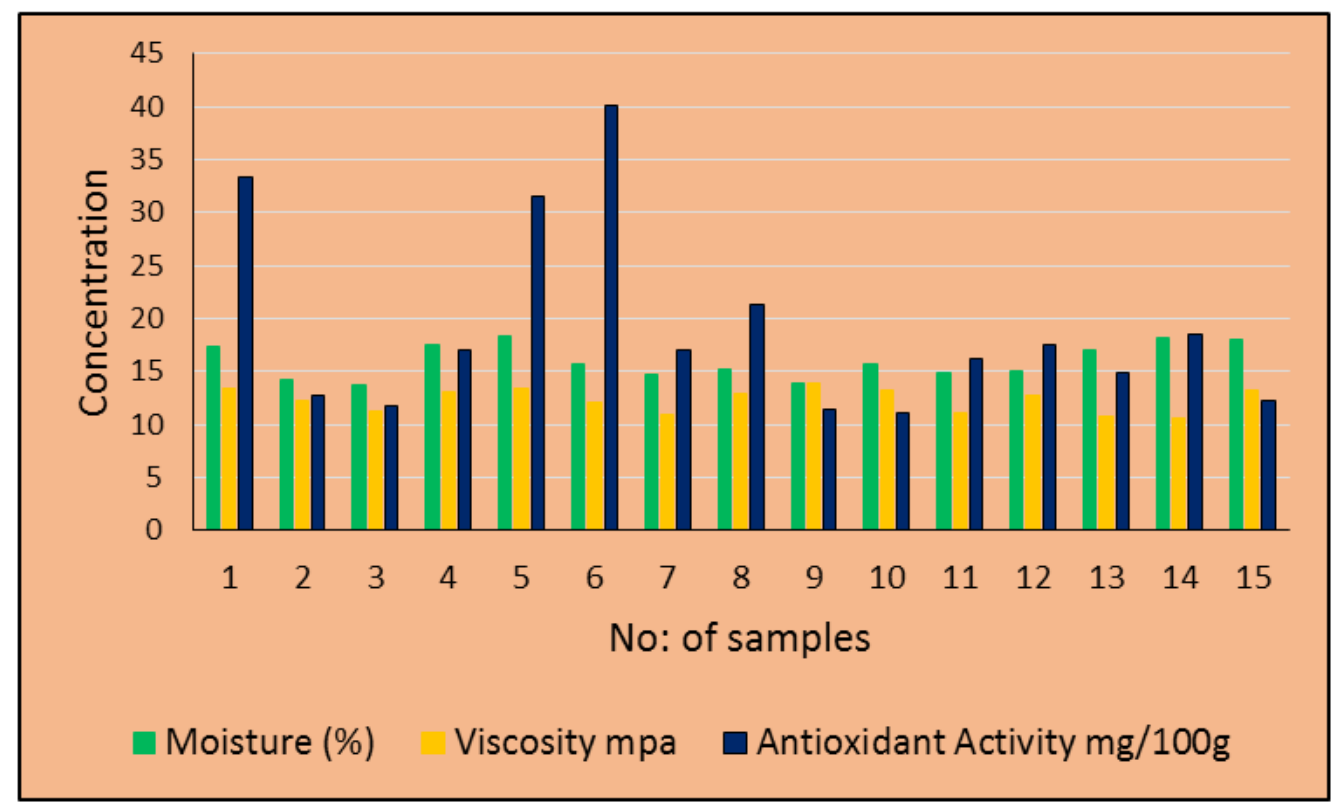

Figure 1. Results of viscosity, moisture and antioxidant activity of honey samples

Viscosity of honey is depend on the moisture\%, temperature, existence of crystals and colloidal particles in the honey product. Various studied have been conducted in the viscosity of honey as role of the temperature at the specific moisture\% ${ }^{[21,22]}$. The moisture content in the honey due to the environmental situations and also handling from beekeepers at time of harvest and it may vary in every year. The higher moisture content due to the crystallization in many kinds of the honey ${ }^{[26]}$. The viscosity content of the honey varied from 10.54 to 13.89 (mpa). The lowest level of viscosity was founded in sample fourteen 10.54 (mpa) and highest was in sample nine 13.89 (mpa). Usually, as rises of temperature, viscosity decrease because there is lower molecular friction and also decrease the hydrodynamic forces. The moisture content in the honey is very important parameter, contributing its stability against granulation and fermentation during storage ${ }^{[27]}$. The current results of moisture content were between 13.8 to $18.3 \%$. The lowest level of moisture was founded in sample three $13.8 \%$ and the highest was in sample five $18.3 \%$. The moisture content of honey varied in different harvest period (table 2, figure 1). 


\subsection{Physico-chemical properties}

The electrical conductivity (EC) is analyzed to check the flow of current from the sample and ions present in the samples. EC is the important physico-chemical determination and for the validation of honeys ${ }^{[23]}$. The results of electrical conductivity was found from 1275 to $4205 \mu \mathrm{s} / \mathrm{cm}$ (table 2, figure 2). The highest result was observed in sample 5 and lowest was in sample 3, high value of electrical conductivity in the honey samples may be due to the environmental condition of area from honey samples were collected. The $\mathrm{pH}$ is defined as concentration of hydrogen ion, it measures the acidity and alkalinity of the sample ${ }^{[24]}$.

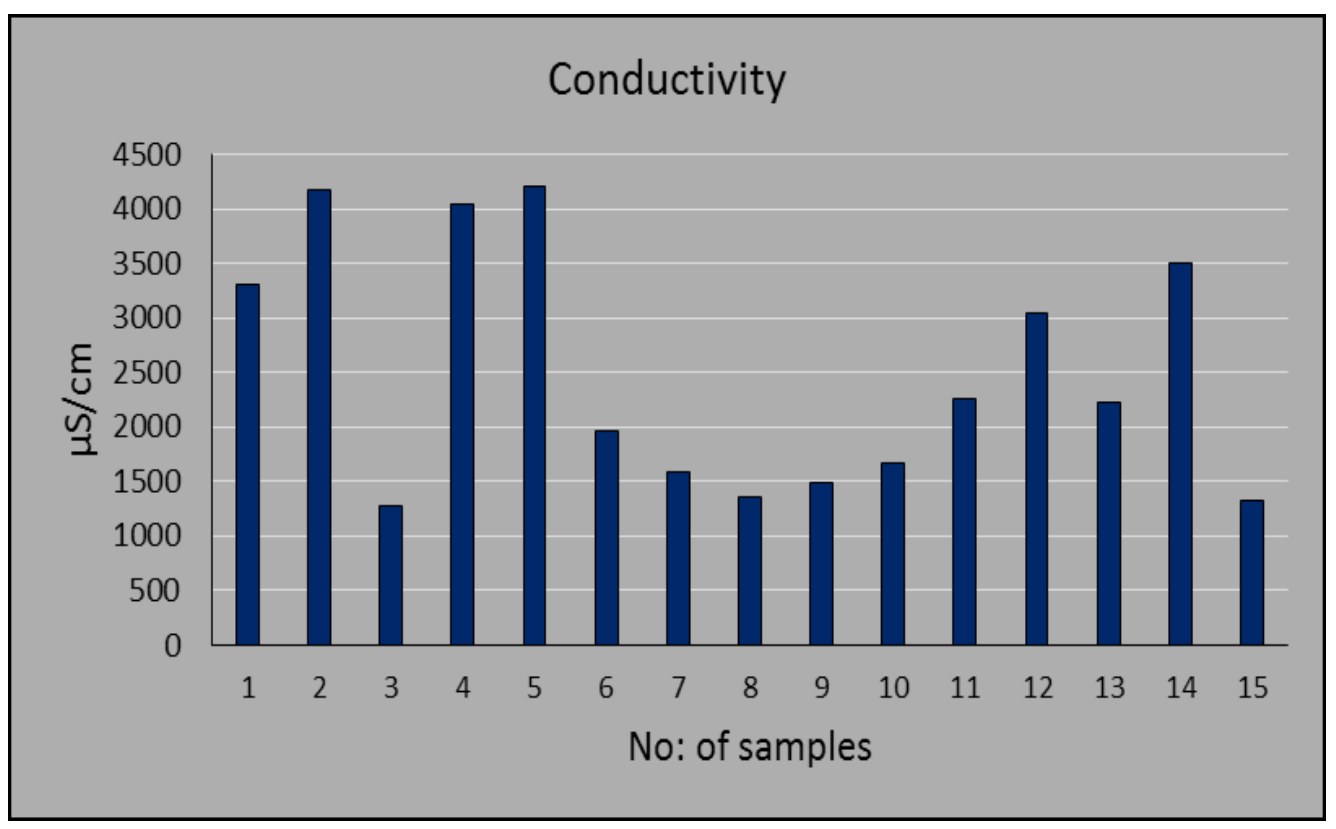

Figure 2. The electrical conductivity results of honey samples

The $\mathrm{pH}$ was observed from 3.21 to 4.31 (figure 3), lowest $\mathrm{pH}$ value was found in sample 3 while highest was in sample 2. The $\mathrm{pH}$ of all samples were acidic in nature. The Ash content is one of the most important parameter related with geographical and botanical origins of the honey samples. The ash content in honey is normally less and due to the nectar composition of the plants ${ }^{[25]}$. The ash content of honey samples varied from 0.30 to $0.46 \mathrm{~g} / 100 \mathrm{~g}$. The lowest level of ash was founded in sample six $0.30 \mathrm{~g} / 100 \mathrm{~g}$ and the highest was in sample fourteen $0.46 \mathrm{~g} / 100 \mathrm{~g}$. The density is temperature dependent and density of honey is higher than other liquid. The density of honey may also increase with the passage of time, if it is more volatile and less dense than components may lost. After significant loss, the density of some honey will rise. It is described as the mass/volume of a constituent. It is mostly described for samples in the units of $\mathrm{g} / \mathrm{mL}$ and $\mathrm{g} / \mathrm{cm} 1$, and also less in the unit of $\mathrm{kg} / \mathrm{m} 3$. The density results of honey samples varied from 0.873 to $0.992 \mathrm{~g} / \mathrm{cm} 1$. The lowest level of density was founded in sample fourteen $0.873 \mathrm{~g} / \mathrm{cm} 1$ and highest was in sample seven $0.992 \mathrm{~g} / \mathrm{cm} 1$ (table 2 , figure 3). 




Figure 3. Results of $\mathrm{pH}$, ash and density of honey samples

Table 2. Results of antioxidant activity and physico-chemical parameters of honey samples

\begin{tabular}{|c|c|c|c|c|c|c|c|}
\hline Sampling stations & $\begin{array}{l}\text { Cond } \\
\mu \mathrm{S} / \mathrm{cm}\end{array}$ & $\mathrm{pH}$ & $\operatorname{Ash}(g / 100 \mathrm{~g})$ & $\begin{array}{c}\text { Moisture } \\
(\%)\end{array}$ & $\begin{array}{c}\text { Density } \\
\mathrm{g} / \mathrm{cm}-1\end{array}$ & $\begin{array}{c}\text { Viscosity } \\
\text { Mpa }\end{array}$ & $\begin{array}{c}\text { Antioxidant } \\
\text { Activity } \mathrm{mg} / 100 \mathrm{~g} \\
\end{array}$ \\
\hline 1 & 3305 & 3.82 & 0.32 & 17.3 & 0.851 & 13.34 & 33.4 \\
\hline 2 & 4170 & 4.31 & 0.31 & 14.2 & 0.793 & 12.32 & 12.75 \\
\hline 3 & 1275 & 3.21 & 0.38 & 13.8 & 0.843 & 11.22 & 11.74 \\
\hline 4 & 4040 & 3.81 & 0.41 & 17.6 & 0.791 & 13.10 & 17.07 \\
\hline 5 & 4205 & 3.76 & 0.45 & 18.3 & 0.754 & 13.43 & 31.5 \\
\hline 6 & 1965 & 3.62 & 0.30 & 15.7 & 0.799 & 12.11 & 40.08 \\
\hline 7 & 1585 & 3.45 & 0.38 & 14.8 & 0.892 & 10.98 & 17.05 \\
\hline 8 & 1350 & 3.28 & 0.35 & 15.2 & 0.797 & 12.98 & 21.35 \\
\hline 9 & 1490 & 3.87 & 0.39 & 13.9 & 0.722 & 13.89 & 11.49 \\
\hline 10 & 1670 & 4.01 & 0.33 & 15.8 & 0.711 & 13.21 & 11.09 \\
\hline 11 & 2250 & 3.92 & 0.40 & 14.9 & 0.786 & 11.12 & 16.18 \\
\hline 12 & 3035 & 4.10 & 0.43 & 15.0 & 0.776 & 12.78 & 17.46 \\
\hline 13 & 2230 & 3.56 & 0.44 & 17.1 & 0.689 & 10.79 & 14.87 \\
\hline 14 & 3495 & 4.23 & 0.46 & 18.2 & 0.683 & 10.54 & 18.59 \\
\hline 15 & 1325 & 3.79 & 0.34 & 18.0 & 0.821 & 13.24 & 12.26 \\
\hline Minimum & 1275 & 3.21 & 0.3 & 13.8 & 0.683 & 10.54 & 11.09 \\
\hline Maximum & 4205 & 4.31 & 0.46 & 18.3 & 0.892 & 13.89 & 40.08 \\
\hline Mean & 2492.67 & 3.78 & 0.38 & 15.98 & 0.78 & 12.34 & 19.12 \\
\hline $\begin{array}{l}\text { Standard } \\
\text { Deviation }\end{array}$ & 1107.2 & 0.32 & 0.05 & 1.61 & 0.06 & 1.12 & 8.88 \\
\hline
\end{tabular}

\section{Statistical analysis}

\subsection{Coefficient of correlation}

Coefficient of correlation is used to check the degree of similarity between the dissimilar variables ${ }^{[12]}$. The coefficient of correlation among 7 physicochemical parameters $\mathrm{pH}$, electrical conductivity, ash, moisture, density, viscosity and antioxidant activity were calculated by computer program SPSS Statistics 22 software. The results were based on average value and examine relationship between different variables, one variable exhibits the prediction of other (table 3). The results indicate that antioxidant activity was less correlated with EC, moisture, density, viscosity and negative correlated with $\mathrm{pH}$ and ash. EC was moderate correlated to $\mathrm{pH}(0.5-0.7)$, less correlated to ash, moisture, viscosity and antioxidant activity $(<0.5), \mathrm{pH}$ was less correlated with ash, moisture and viscosity and negative correlation to density and antioxidant activity. Ash was less correlated to moisture but negative correlated to others parameters. Moisture and density were less 
correlated to viscosity and antioxidant activity, viscosity was less correlated to antioxidant activity.

Table 3. Correlation determination of seven parameters of the honey samples

\begin{tabular}{|c|c|c|c|c|c|c|c|}
\hline \multicolumn{8}{|c|}{ Correlation Matrix } \\
\hline Correlation & Conductivity & $\mathrm{pH}$ & Ash & Moisture & Density & Viscosity & Antioxidant \\
\hline Conductivity & 1.000 & & & & & & \\
\hline $\mathrm{pH}$ & 0.594 & 1.000 & & & & & \\
\hline Ash & 0.296 & 0.078 & 1.000 & & & & \\
\hline Moisture & 0.434 & 0.174 & 0.323 & 1.000 & & & \\
\hline Density & -0.178 & -0.441 & -0.469 & -0.268 & 1.000 & & \\
\hline Viscosity & 0.094 & 0.136 & -0.319 & 0.091 & 0.030 & 1.000 & \\
\hline Antioxidant & 0.282 & -0.140 & -0.182 & 0.343 & 0.196 & 0.139 & 1.000 \\
\hline
\end{tabular}

\subsection{Cluster analysis}

Hierarchical cluster analyzed to examine the similarity among the groups ${ }^{[28,29]}$. The dendrogram grouped all 15 sampling stations into four statistically clusters. Cluster 1 comprises three samples 11.13 and 6, cluster 2 contains six samples 8, 15, 3, 7, 10, 9 and cluster 3 comprise three samples 2, 5, 4 and cluster 4 contains three samples 1, 14, 12 (figure 4). It is observed that cluster 4 was highest results of parameters than other clusters, cluster 3 were higher results of parameters than cluster 2 and cluster 2 were higher results of parameters than cluster 1.

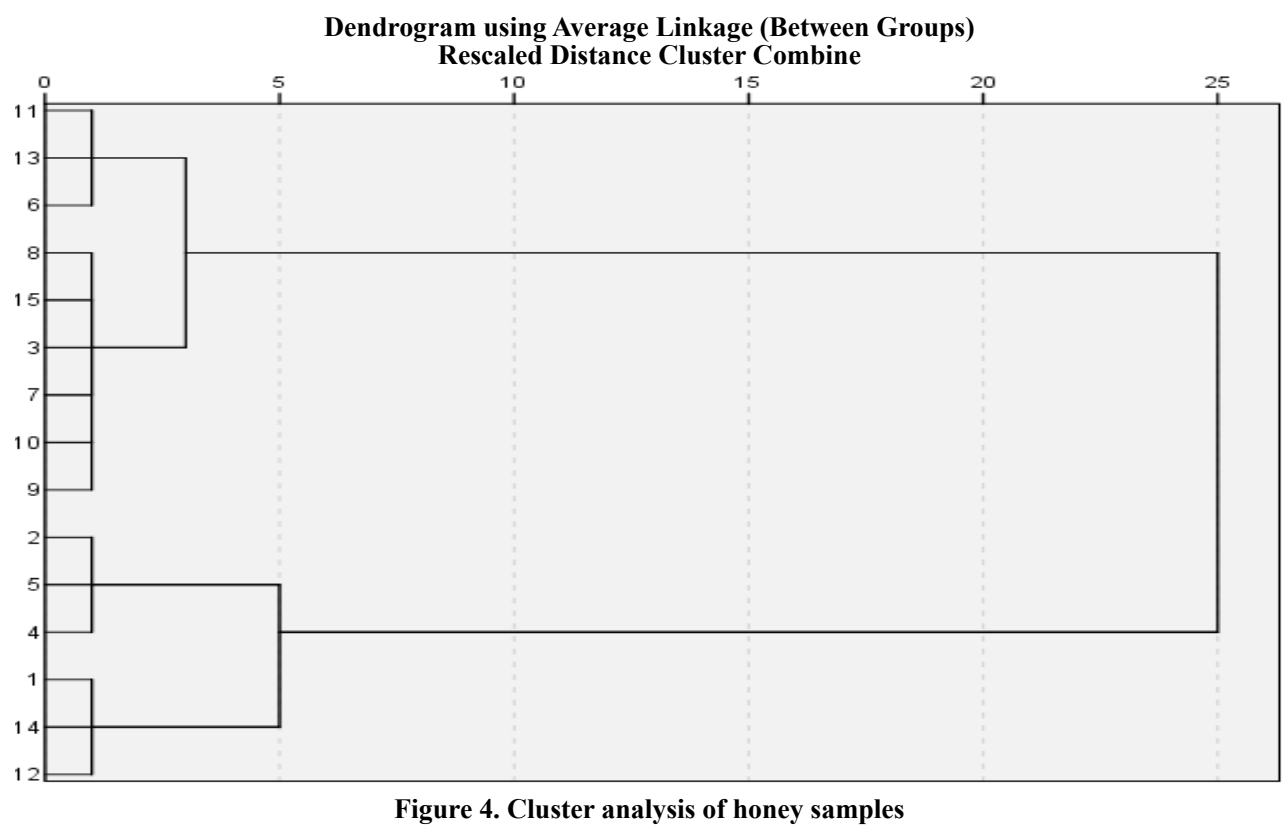

\subsection{Principal component analysis (PCA)}

Principal components analysis (PCA) was carried out using SPSS 22 Software. It is a tool which attempts to clarify the variance of the dataset of inter correlated variables with smaller set of the independent variables ${ }^{[29]}$. PCA extracts eigenvalues from covariance matrix of original variables and is weighted linear combination of the original variables. The rotated components matrix for 7 parameters for the honey samples were shown in (table 4). It includes loading components for rotated matrix, eigenvalues for every component and cumulative $\%$ of variance explained in each component. It shows that 3 principal components account together for $71.153 \%$ of the total variance of the dataset. In which the first component is $33.052 \%$, second component $55.901 \%$ and third component $71.153 \%$ of total variance. The eigenvalues of three components are greater than 1 , and can be used to assess the dominant hydrogeochemical process. The component 1 which is based on loading $33.052 \%$ indicated for parameters $\mathrm{pH}$, electrical conductivity, ash, moisture, density, viscosity and antioxidant with negative to positive high loading ( negative to 0.888 ), The component 2 which has $22.849 \%$ loading indicated high loading for moisture and antioxidant $(0.769,0.807$ respectively). The component 3 which has $17.252 \%$ loading with high positive loading for viscosity $(0.749)$, less positive loading for $\mathrm{pH}$, electrical conductivity and antioxidant. 
Table 4. Principal component analysis (PCA) of the parameters of honey samples

\begin{tabular}{cccc}
\hline & \multicolumn{2}{c}{ Rotated Component Matrix } \\
\hline Parameters & Components & PCA (3) \\
& PCA (1) & PCA (2) & 0.026 \\
Conductivity & 0.578 & 0.620 & 0.181 \\
pH & 0.888 & 0.063 & -0.812 \\
Ash & 0.325 & 0.173 & -0.218 \\
Moisture & 0.242 & 0.769 & 0.391 \\
Density & -0.701 & 0.026 & 0.749 \\
Viscosity & 0.229 & 0.130 & 0.236 \\
Antioxidant & -0.320 & 0.807 & 1.208 \\
Eigenvalues values & 2.314 & 1.599 & 17.252 \\
\% of Variance & 33.052 & 22.849 & 73.153 \\
Cumulative $\%$ & 33.052 & 55.901 & \\
\hline
\end{tabular}

\section{Conclusion}

The present research work total 15 samples were analyzed for 7 parameters. The $\mathrm{pH}$ level was found in acidic nature but found between in the acceptable range. The electrical conductivity was found in higher concentration in half of honey samples. The analyzed honey samples were rich in moisture and viscosity contents and has good antioxidant activity in samples but ash\% were founded slightly low. The statistical analysis like correlation coefficient, principal component analysis (PCA) cluster analysis were also determined to interpreting the results. The results indicate that the samples were compare favorably with others samples in various portions of the study area and under the limits of international standards. It is observed that the results of local honey rich in concentration of parameters but founded less concentration in branded honey which were purchased from local market. It is reveal that local honey is more favorable than branded honey but branded honey may be used for nutritional purposes and human consumption.

\section{Reference}

[1] Ajani O. O. Physical characterisation of some honey samples from North-Central Nigeria. International Journal of Physical Sciences. 2009; 4(9): 464-470.

[2] White J, Doner L. W. Honey composition and properties. Agricultural Research Service, United States Department of Agriculture, 1980; 82-91.

[3] Jeffrey A. E, Echazarreta C. M. Medical uses of honey. Rev Biomed. 1996; 7(1): 43-49.

[4] Cantarelli M. A, Pellerano R. G, Marchevsky E. J, Camina. Quality of honey from Argentina: study of chemical composition and trace elements. The Journal of the Argentine Chemical Society. 2008; 96: 33-41.

[5] Omafuvbe B. O, Akanbi O. O. Microbiological and physico-chemical properties of some commercial Nigerian honey. African Journal of Microbiology Research. 2009; 3(12): 891-896.

[6] Zaghloul A. A, El-Shattawy H. H, Kassem A. A, et al. Honey, a prospective antibiotic: extraction, formulation, and stability. Die Pharmazie. 2001; 56(8): 643-647.

[7] Al-Waili N. S. Topical application of natural honey, beeswax and olive oil mixture for atopic dermatitis or psoriasis: partially controlled, single-blinded study. Complementary therapies in medicine. 2003; 11(4): 226-234.

[8] Zahoor M, Naz S, Sangeen M. Antibacterial, antifungal and antioxidant activities of honey collected from Timergara (Dir, Pakistan). Pak. J. Pharm. Sci. 2014; 27(1): 45-50.

[9] Ahmed M, Imtiaz Shafiq M, Khaleeq A, et al. Physiochemical, biochemical, minerals content analysis, and antioxidant potential of national and international honeys in Pakistan. Journal of Chemistry. 2016; http://dx.doi. org/10.1155/2016/8072305.

[10] Gulfraz M, Ifftikhar F, Asif S, et al. Quality assessment and antimicrobial activity of various honey types of Pakistan. African journal of Biotechnology. 2010; 9(41): c-6906.

[11] Farooq Khan Z, Maqbool T. Physical and spectroscopic characterization of Pakistani honey. Ciencia e investigación agraria. 2008; 35(2): 199-204.

[12] Lanjwani M F, Channa F. A. Minerals content in different types of local and branded honey in Sindh, Pakistan. Heliyon. 2019; 5(7): e02042.

[13] Lanjwani M. F, Khuhawar M. Y, Jahangir Khuhawar T M, et al. Risk assessment of heavy metals and salts for human and irrigation consumption of groundwater in Qambar city: a case study. Geology, Ecology, and 
Landscapes. 2019; 4(1): 23-39.

[14] Khuhawar M. Y, Brohi R. O. Z, Jahangir T. M, et al. Water quality assessment of ramser site, indus delta, Sindh, Pakistan. Environmental monitoring and assessment. 2018; 190(8): 492.

[15] Astm D. Standard test method for kinematics viscosity in crude oil. West Conshohocken, PA: ASTM International $7042 ; 2004$.

[16] Official Methods of Analysis Association of Official Analytical Chemists, AOAC. 16th Ed, Washington, D.C, 1995.

[17] Official Methods of Analysis Association of Official Analytical Chemists p. 15th Ed, Washington, D.C, 1990.

[18] Prieto P, Pineda M, Aguilar M. Spectrophotometric quantitation of antioxidant capacity through the formation of a phosphomolybdenum complex: specific application to the determination of vitamin E. Analytical biochemistry. 1999; 269(2): 337-341.

[19] Khalil M. I, Sulaiman S. A, Boukraa L. Antioxidant properties of honey and its role in preventing health disorder. The Open Nutraceuticals Journal. 2010; 3(1): 6-16.

[20] Grune T. Free radicals and diseases: gene expression, cellular metabolism and pathophysiology (Vol. 367). (Ed.) IOS press; 2005.

[21] Junzheng P, Changying J. General rheological model for natural honeys in China. Journal of Food engineering. 1998; 36(2): 165-168.

[22] Sopade P. A, Halley P, Bhandari B, et al. Application of the Williams-Landel-Ferry model to the viscosity-temperature relationship of Australian honeys. Journal of Food Engineering. 2003; 56(1): 67-75.

[23] Mateo R and Bosch-Reig F. Classification of Spanish unifloral honeys by discriminant analysis of electrical conductivity, color, water content, sugars, and pH. Journal of Agricultural and Food Chemistry. 1998; 46(2): 393400.

[24] Sanz M. L, Gonzalez M, De Lorenzo C, et al. A contribution to the differentiation between nectar honey and honeydew honey. Food Chemistry. 2005; 91(2): 313-317.

[25] Al-Khalifa A. S, Al-Arify I. A. Physicochemical characteristics and pollen spectrum of some Saudi honeys. Food chemistry. 1999; 67(1): 21-25.

[26] Anupama D, Bhat K. K, Sapna V. K. Sensory and physico-chemical properties of commercial samples of honey. Food research international. 2003; 36(2): 183-191.

[27] Singh N, Bath P. K. Quality evaluation of different types of Indian honey. Food Chemistry. 1997; 58(1-2): 129-133.

[28] Chen K, Jiao J. J, Huang J, et al. Multivariate statistical evaluation of trace elements in groundwater in a coastal area in Shenzhen, China. Environmental Pollution. 2007; 147(3): 771-780.

[29] Lanjwani M. F, Khuhawar M. Y, Khuhawar, T. M. J. Groundwater quality assessment of Shahdadkot, Qubo Saeed Khan and Sijawal Junejo Talukas of District Qambar Shahdadkot, Sindh. Applied Water Science. 2020; $10(1): 26$. 